lader det ikke til, at nogen befinder sig i dette centrum, med undtagelse af nogle sygelige tilfæelde, og alligevel er denne tolkning:

grundlaget for fans'enes forsog på få et særligt forhold til deres idol (nJeg ved, at de fleste af dine fans elsker dig pa grund af din rolle i serien, men det er ikke derfor, jeg kan lide dig «)

grundlaget for de parodierende tolkninger. Parodi er en spog med den sygelige fan, der ikke kan leve uden sit program, og som lever sig ind i det, som om det var en virkelig verden

grundlaget for de almindelige tolkninger, for den påvirker undergrupper (pigerne, de yngste), som man vil tage afstand fra i presentationen af sig selv som tv-seer på den sociale scene.

En fan siges altid at vare en anden person end én selv. Det forer til konstruktionen af tolkningsfallesskaber, der bygger på en formodning om, at der findes en afvigende tolkning og et ekstremt forhold til tv. Når alt kommer til alt, er det să ikke også den underforståede mening i den kultiverede kritik af fjernsynet? Forestillingen om, at programmerne er skadelige for dem, der ser dem, bygger indirekte pá en afstandtagen til de formodede farer ved fiktionens verden. At der rent faktisk sjaldent eksisterer nogen fare har ikke sa stor betydning, for ved af tage afstand til den, fastslăr man, at man ikke er en del af den. Den formodede fare bruges derfor $i$ høj grad strategisk.

\section{Noter:}

1. Et prioniteret uddannelsesomràde, Zone dFducation Prioritain, er en lovbestemt zone i Frankrig, hvor visse uddannelses-institutioner modtager supplemrende statsstotte for at bekmpe uligheder på uddannelsesomràdet (overs.).
2. Promiers Batsers er en fransk serie for unge (overs.)

3. Le Mid el les abelles er ligeledes en fransk serie for unge (overs.).

4. Minitel er et fransk telekommunikationssystem med adgang til databank (overs.).

5. LInstitut d'Etudes Politiques de Pavis en en hojere lareanstalt med meget hårde optagelseskriterier. Studenterne kalder den wSciences Pó (for Politiske Studier).

6. En anden fransk serie af meget dårlig kvalitet, der sendes om naten.

7. Bravo Ginl! er et ungdomsblad for unge, der tematiserer de unges forste seksuelle erfaringer.

\section{Litteratur}

Allen Richard (1985): Speaking of Soap Operas. Chapel Hill: University of North Carolina Press.

Brown, Marym Ellen (1994): Soap Operas and Womens Talk London: Routledge.

Chalvon-Demersay. S, og Pasquicr, Dominique (1990): Dróles de stass, la lélevision des animalours. Paris: Aubier.

Dayan, Daniel og Katz, Elihu: Media Events: the Live Broadcasting of History. Cambridge, MA: Harvard University Press.

Eco, Umberto (1993): De Superman au sumomme Paris: Grasset.

Goffmann, Erwin (1959): The Presentation of Selfin Everyday Life. Garden City, NY: Doubleday.

Hoggart, Richard (1977): The Uses of Literacy: Aspects of Working-Class Life with Special Reference to Publications and Entertaiments. Harmondsworth: Penguin. Opr. 1957.

Liebes, Tamar (1994): A propos de la participation du téléspectateur. Réseaux 64.

Matelsk, Marilyn (1988): The Soap Opera Evolution. Jefferson $\mathrm{NG}$. McFarland.

Pasquier, Dominique (1996): "Teen series: Reception. Television, Adolescense, and Culture of Feclingsk. Childhood nx.3. London: Sage.

Radway, Janice (1985): Reading the Romano. Chapel Hill: University of North Garolina Press. 


\title{
Kommunikationsstrategier i danske sundhedsinformerende brochurer (1)
}

\author{
Af Bo Laursen
}

\begin{abstract}
Hvilke kommunikationsstrategiske overvejelser ligger bag udformningen af sundhedsinformerende brochurer? Hoori består den retoriske udformning af budskaberne og hwilke genremessige arketyper findes indenfor netop sundhedsinformerende brochurer? Dette er nogle af de spargsmal forfatteren besvarer $i$ artiklens diskursanalyse af 13 danske brochurer. Ialt 5 mikrohandlinger identificeres som genrens prototypiske rygrad og 2 arketyper opstilles, nemlig henholdsvis den straditioneller og den smodernew sundhedsinformerende brochure.
\end{abstract}

Diskursproduktion er en kognitiv proces, der er kendetegnet ved at afsender er tvunget til at foretage et stort antal valg, der relaterer sig til udformningen af det budskab, som han ønsker at kommunikerc. Hvert valg forctages - bevidst eller ubevidst - i forhold til forskellige parametre som f.eks. tema, kommunikativt formål, målgruppe, medium, psykologisk relation mellem afsender og modtager m.m. Diskursproduktion er således en strategisk aktivitet forstået på den måde, at hvert funktions- og formvalg er resultatet af en overvejelse om, hvad der er mest formålstjensligt under de givne kommunikative omstændigheder.

I denne artikel præesenteres resultaterne af en analyse af et korpus af danske sundhedsinformerende brochurer. Brochurerne er analyseret med det formal at beskrive udvalgte aspekter af de strategier, som brochureproducenterne har anvendt $i$ deres losning af en bestemt kommunikationsopgave.

Ved 'sundhedsinformation' forstås i det folgende forskellige kommunikative aktiviteter, som har til formål at fă modtagerne til at ændre visse typer af adfæerd, som afsender anser for sundhedsskadelige. Eksempelvis gores der fra forskellig side en ihærdig kommunikativ indsats for at fa den danske befolkning til at holde op med at ryge, fordi tobaksrygning antages at fremkalde kræftsygdomme. Dyrk motion!, Spisftere gronsager! Nedsat dit alkoholforbrug!, Dyrk sikker sex! er eksempler på budskaber af samme type. Den sundhedsinformation, der her er tale om, fokuserer på sammenhangen mellem visse typer af livsstil (adfxrd) og sygelighed, og de sygdomme der er i fokus, benavnes da også ofte 'livsstilssygdomme'.

Budskaberne formidles på mange forskellige måder, bl.a. via plakater, foredrag, avis- og ugcbladsannoncer, udstillinger, busstreamers, undervisning, TV-og radioudsendelser, brochurer, foldere $\mathrm{m} . \mathrm{m}$. De undersøgelsesresultater der rapporteres $\mathrm{i}$ denne artikel vedrører udelukkende budskaber formidlet gennem brochurer og foldere (2).

I stedet for at anvende betegnelser som (sundheds-) 'information' og (sundheds-) 'oplysning' om denne type af kommunikationsaktiviteter burde man ud fra et funktionelt synspunkt snarere anvende betegnelsen 'adfærdspåvirkning'. Formidling afinformationer om sundhed indgăr ganske vist som et element i denne type af kommunikationsaktiviteter, men her som i alle andre tilfalde, hvor informationsformidling finder sted, har denne en dybereliggende funktion. Brochureproducenterne informerer således ikke blot for informationens egen skyld, men i håbet om at de formidlede informationer forer til en adferdsændring hos mălgruppen Sundhedsinformerende brochurer tilhorer den type af diskurser, som i dele af den engelsksprogede diskursanalytiske litteratur omtales som hortatory discourse, og som Longacre beskriver således:

Hortatory discourse aims at influencing conduct, that is, getting the receivers of the text to do som 
mething they are not currently doing, to discontinue doing something they are doing, to continue doing something they are already doing, to expend greater effort in an activity already embarked on, to modify the nature of their efforts, and so on $(1992,109)$

Sakkaldt sundhedsinformerende kommunikationsaktiviteter er interessante ud fra et kommunikationsstrategisk synspunkt. Den kommunikationsopgave som afsender skal lose er nemlig vanskeliggiort af mindst folgende to forhold. Eftersom aktiviteterne har et praventivt sigte, bestăr målgruppen for det forste primært af mennesker, der ikke er syge og/eller ikke nodvendigvis foler sig truet af sygdom og derfor formentlig ikke foler noget starkt incitament til at andre livsstil. For det andet er der tale om en kommunikationsopgave, hvis mál det er at påvirke sådanne aspekter af det enkelte menneskes livsforelse, som af mange opfattes som helt private. Disse to forhold, der tilsammen udgor en alvorlig kommunikationsbarriere mellem afsender og modtager og derfor vanskeliggor kommunikationsplanlæggernes opgave, stiller helt sarlige krav til budskabets retoriske udformning. Det er denne retoriske udformning, jeg sigter til med begrebet kommunikationsstrategi, og som er temaet for denne artikel (3).

\section{Datamateriale}

Undersagelsen baserer sig på 13 brochurer, udgivet mellem 1985 og 1995 (4). Brochurerne omhandler emnerne motion ( 1 stk.), kost (3 stk.), rygning (6 stk), alkohol (2 stk.) og sex (1 stk.) og cr produceret af organisationer, som ser det som en af deres opgaver at arbejde for at fremme befolkningens sundhed bla. gennem sygdomsforebyggende aktiviteter(5). De fleste af de involverede organisationer besidder en specialviden og har en interesse ict bestemt sundhedsfagligt område. Organisationerne koncentrerer derfor typisk deres aktiviteter om enten én type sygdomme og de typer af social adford, der antages at fremkalde disse (f.eks. Krreftens Bekæmpelse, Hjerteforeningen og Astma- Allergiforbundet) eller om én type af social adfard og de sundhedsmassige risici, der er forbundet hermed (f.eks. Rådet for Storre Fardselssikkerhed og Tobaksskaderådet). Atter andre - f.eks. Sundhedsstyrelsen, Sundhedsministeriet og amteme- arbejder mere generelt med sundhedsfremme.

Jeg har udvalgt datamaterialet ud fra antagel- sen om, at der cksisterer en tæt sammenhang mellem kommunikationssituation og budskabsudformning. For at sikre sammenligneligheden af de tekster, der indgår i datamaterialet, har jeg derfor valgt at lagge en vurdering af folgende tre kommunikativt relevante parametre til grund for sammensatningen af mit tekstkorpus: 1) teksterne skal have samme kommunikative formål, 2) budskabet skal vare formidlet via samme medium og 3 ) teksterne skal henvende sig til mălgrupper som på vasentlige punkter (bredde, sundhedstilstand $\mathrm{og}$ forhåndsviden om tekstens tema) udviser fallestrak. Fastlæggelsen af disse tre kommunikative parametre skal sikre, at irrelevante tekster frasortcres. I det folgende skal jeg kort karakterisere, såvel de tekster som falder inden for undersogelsens rammer, som de der falder udenfor.

De udvalgte teksters kommunikative formäl antages som nævnt at vare at fă mälgruppen til at ændre en social adfard, som afsender anser for at have uheldige sundhedsmassige konsekvenser for målgruppen. Dette formål satter fokus på såvel sundhed (tema) som adfardsendring (hensigt). Ved at lade netop dette kommunikative formal vare et af udvalgelseskriterierne, udelukkes for det forste adfardsregulerende tekster, der opererer inden for andre omrăder end sundhedsområdet (f.cks. kommerciel og politisk marketing og debatindleg). For det andet udelukkes tekster inden for sundhedsområdet, som ikke har til formal at andre målgruppens adfærd (f.eks. tekster der omhandler en bestemt sygdom og dennes læge- og sygeplejefaglige behandling).

De udvalgte tekster er af samme type, hvad angår medium. Der er tale om brochurer af et omfang på mellem ca. $700 \mathrm{og} \mathrm{ca} .4 .000 \mathrm{ord}$. Teksterne er for de flestes vedkommende trykt i flere farver og forsynet med illustrationer (fotos, tegninger, grafik m.m.) (6), er sædvanligvis gratis og distribueres primært via biblioteker, apoteker, praktiserende lager m.m.

De tekster der indgår i datamaterialet henvender sig til en málgnuppe, jeg vurderer til 1) at vare relativt bred (f.eks. (kvindelige) rygere; personer med vægtproblemer; (mandlige) bilister; kvinder i almindelighed) 2) ikke at besidde ekspertviden pá do emneomräder som teksterne omhandler, og 3) at vare raske mennesker. Jeg udelukker dermed tekster som henvender sig til en relativt snaver og dermed socio-kulturclt relativt mere homogen målgruppe (f.eks. 16-19-ârige piger i storbyer; midaldrende bosniske flygtninge fra landområder), til 
personer som har en seerlig forhandsviden om teksternes emner (f.eks. læger, sygeplejersker, ernæringseksperter, trafiksociologer) og til personer der allerede har faet konstateret en skade eller sygdom (f eks. kraftpaticnter, personer med konstaterede hjerte-/kredslobsproblemer, personer der anser deres overvagt for at vare et sundhedsproblem). Der er m.a.o. tale om bredt anlagt kommunikation fra en ekspertinstans til en lagmand, der - hvis han kendte teksternes kommunikative formål - ikke nødvendigvis ville føle behov for at lase tcksterne.

\section{Tekster som målrettede handlinger}

Min tilgang til datamaterialet tager udgangspunkt i den grundlaggende idé, at producenter af sundhedsinformerende tekster anvender teksterne til at udfore en handling, der er rettet mod en målgruppe og styret af et formål. I dette afsnit skal jeg uddybe dette metodiske udgangspunkt.

Sundhedsinformerende brochurer er et prototy. pisk eksempel på, hvad man kunne kalde brugstekster. Begrebet 'brugstekster' cr svart at definere pracist, men skal her forstås som tekster, der i modsæetning til de fleste litterare tekster produceres med henblik på at lose en veldefineret kommunikationsopgave. Folgelig indskriver brugstekster sig som oftest i en relativt pracis kommunikationssituation, hvilket bl.a. betyder, at producenterne af sădanne tekster som oftest $\mathrm{cr}$ fuldt bevidste om tek. sternes formål og teksternes målgruppe. Pă denne baggrund forekommer det naturligt at opfatte sundhedsinformerende brochurer som tekster, der fungerer som redskab i udforelsen af en rationel handling. Begrebet 'rationel handling'skal forståes som menneskelig adfard, der er styret af bevidstheden om, at en adfærds hensigtsmassighed skal vurderes i forhold til adferdens formanl. Dette syn pa brugstekster betoner to vesentlige aspekter, nemlig handlingsaspektet og strategiaspektet. Strategiaspektet er kort omtalt $i$ artiklens indledning og vil blive yderligere berørt senere. I dette afsnit uddybes handlingsaspektet.

Det var sproghandlingsteorien, der introducerede ideen om, at vi anvender sprog til at udfore handlinger. Men mens sproghandlingsteorien typisk arbejder med enkeltstående og dekontekstualiserede ytringer, foreslär jeg at betragte hele tekster som handlinger, der udfores i en social kontekst.
I det folgende foretager jeg en skelnen mellem 'sproglige handlinger' og 'ikke-sproglige handlinger? H vis man ser bort fra den afgorende forskel mht. sprogets tilstedeværelse/fravær, minder de to handlingstyper meget om hinanden. For såvel sproglige som ikke-sproglige handlinger galder det sâledes, 1) at man kan skelne mellem handlingens formal og dens udforelse, og 2) at en given handling (makrohandlingen) kan betragtes som bestående af en rakke delhandlinger (mikrohandlinger).

Makrohandlingen 'at vaske vinduer' er et eksempel på cn ikke-sproglig handling. Denne handling udfores typisk v.h.a. folgende tre mikrohandlinger: 1) URENHEDER LOSNES, 2) URENHEDER FJERNES, 3) VINDUET SLUTBEHAND-LES/ VAND FJERNES. Ved en mikrohandling forstår jeg en handling, der bidrager til indfrielsen af en overordnet handlings (dvs. makrohandlingens) formål. Såvel makrohandlinger som mikrohandlinger er defineret ved deres formål. Formảlet med makrohandlingen 'at vaske vinduer' er (som regel) at oge vinduernes transparens. De tre mikrohandlingers formål fremgår af de funktionelle betegnelser, jeg ovenfor har anvendt til at beskrive dem (7).

Ligesom en given makrohandling (defineret ved sit formål) kan udfores på forskellige måder dvs. forskellige (konfigurationer af) mikrohandlinger kan indgà $i$ handlingens udforelse - kan en given mikrohandling (ligeledes defineret ved sit formål) udfores på forskellige måder. Således kan mikrohandling 1 (URENHEDER LOSNES) udfores på bl.a. følgende måder: a) med armbevægelser fra oven og nedefter păføres sprit med en klud; b) med armbevagelser fra neden og opefter påfores serligt vinduespudsemiddel med en svamp; c) med diagonale armbevægelser påfores sulfovand med en borste. Tilsvarende beskrivelser af forskellige mulige udforelser kan naturligvis udarbejdes for mikrohandlingerne $2 \mathrm{og} 3$. Fig. l opsummerer beskrivelsen af en bestemt udforelsc af den ikkesproglige makrohandling 'at vaske vinduer.

At vaske vinduer'er en ikke-sproglig handling, men også sproglige handlinger kan med fordel betragtes som bestående af en rakke mikrohandlinger, hver defineret ved sit formål. For sproglige handlinger galder det - ligesom det er tilfaldet for ikke-sproglige handlinger - at den der udforer makrohandlingen og de mikrohandlinger, denne bestar af, har mulighed for at valge den udforelse, som han finder mest hensigtsmassig $\mathrm{i}$ forhold til formalet. 


\begin{tabular}{|c|c|c|c|}
\hline Makrohandling & \multicolumn{3}{|c|}{ Mikrohandlinger } \\
\hline \multirow{4}{*}{$\begin{array}{l}\text { AT VASKE } \longrightarrow \\
\text { VINDUER } \longrightarrow\end{array}$} & & Funktion & Udforelse \\
\hline & 1 & LOSNE URENHEDER & $\begin{array}{l}\text { Med diagonale armbevagelser paføres } \\
\text { vinduet sulfovand med en børste }\end{array}$ \\
\hline & 2 & FJERNE URENHEDER & Vinduet spules med en vandslange \\
\hline & 3 & SLUTBEHANDLE VINDUET & Vinduet tørres med et viskestykke \\
\hline
\end{tabular}

Fig. 1. Beskrivelse af en bestemt udforelse of den ikke-sproglige (makro-) handling at vaske vinduer'

Den konfiguration af mikrohandlinger som en diskurs (eller en genre) består af, vil jeg kalde diskursens funktionelle makrostruktur. Betragt som eksempel nedenståcnde tekst som udforer handlingen 'at promovere produktet Brillian', og hvis formål er at oge salget af Brilliant på det danske marked (8).

Foler du ogsa en tomhed i dit liv?

Gor som Michael Jackson, brug Brilliant - og du vil blomstre op igen. Hois du kober fem tuber Brilliant inden l. juni, fär du Michael Jacksons myeste CD oven ikobet.

\section{Tekst 1 .}

Som det var tilfeldet med handlingen 'at vaske vinduer', kan ovenstående tekst betragtes som en makrohandling bestående af ct antal mikrohandlinger, hver med sit specifikke formål. Teksten soger at indfri sit formal gennem udforelsen af fire mikrohandlinger. Mikrohandling 1 har som formål at beskrive et problem hos modtager og udfores v.h.a. segmentet Foler du ogsa en tomhed i dit liv? Mikrohandling 2 har som formall at presentere Brilliant som løsningen på problemet og udføres v.h.a. segmentet brug Brilliant - og du vil blomstre op igen. Mikrohandling 3 har som formål at argumentere for losningen og udfores v.h.a. segmentet Gnr som Michael Jackson. Mikrohandling 4 har som formål at tilskynde modtager til at handle (dvs. kobe) og udfores af segmentet Hoisduksber fem tuber Brilliant inden 1. juni, fär du Michael Jacksons nyeste $C D$ ozen $i$ kobet. Fig. 2 opsummerer analysen.
Vi ser altså, at det er muligt at betragte diskurser som konfigurationer af mikrohandlinger. Forskellen mellem sproglige og ikke-sproglige handlinger ligger - ikke overraskende - i udforelsesdimensionen. Sa mens en beskrivelse af mikrohandlingers funktionelle verdi kan udfores efter samme retningslinjer for de to handlingstyper, må der anvendes to forskellige typer beskrivelsesvacktojer, når det galder beskrivelser af udforelsesdimensionen. I den resterende del af dette afsnit skitserer jeg de principper og den terminologi, jeg vil anvende i min beskrivelse af de sproglige handlinger, der findes i denne undersøgelses datamateriale. Jeg vil fokusere på udførelsesdimensionen.

\section{Analyse og beskrivelse af sproglige handlinger}

Det er ikke nogen ny idé at betragte tekster som bestảende af et antal segmenter med hver sin funktionelle vardi i forhold til helheden. Denne tankegang findes eksempelvis hos funktionelt orienterede angelsaksiske genreanalytikere som f.cks. J. Swales, V. Bhatia, J. R. Martin og S. Eggins, der alle betragter en analyse af diskursers konfiguration af mikrohandlinger som en integreret del af genreanalysen. I denne tradition opfattes en genre som måden, hvorpå en bestemt opgave udfores, når (et givet) sprog anvendes til udføre opgaven. I forlængelse heraf bliver det en af linguistens opgaver at beskrive så precist som muligt, hoordan sproget anvendes til at udfore forkhellige opgaver. Folgelig består genreanalyse primart $\mathrm{i}$ at beskrive diskursgenrers funktionelle makrostrukturer (konfigurationer af mi- 


\begin{tabular}{|c|c|c|c|}
\hline Makrohandling & \multicolumn{3}{|c|}{ Mikrohandlinger } \\
\hline \multirow{5}{*}{$\begin{array}{l}\text { AT PROMOVERE } \\
\text { PRODUKTET } \\
\text { BRILLIANT }\end{array}$} & & Funktion & Udforelse \\
\hline & 1 & BESKRIVE PROBLEM & Foler du ogsà en tomhed i dit liv? \\
\hline & 2 & PRASENTERE EN LøSNING & $\begin{array}{l}\text { Brug Brilliant - og du vil blomstre } \\
\text { igen }\end{array}$ \\
\hline & 3 & ARGUMENTERE & $\begin{array}{l}\text { Gor som Michael Jackson, (brug } \\
\text { Brilliant ...) }\end{array}$ \\
\hline & 4 & TILSKYNDE TIL HANDLING & $\begin{array}{l}\text { Hvis du kober fem tuber Brilliant } \\
\text { inden l. juni, far du Michael } \\
\text { Jacksons nyeste CD oven i kobet }\end{array}$ \\
\hline
\end{tabular}

Fig. 2. Handlingsorienteret beskrivelse af Tekst 1 ( = den sproglige (makro-) handling 'at promontere produktet Brilliant')

kro-handlinger) og mikrohandlingernes udforelse. Udforelselsdimensionen af sprogligt udforte mikrohandlinger vil jeg $i$ det følgende betegne som '(diskursiv) form. Om den funktionelle makrostruktur hedder det bl. a.: $\gg$ It [den funktionelle makrostruktur (9). BL] depends upon the communicative purpose(s) that it serves in the genre and that is why it varies from one genre to another (Bhatia 1993, 32) «. Om den funktionelle makrostrukturs byggesten, mikrohandlingerne (som hos Eggins og Martin benævncs stages og hos Swales og Bhatia moves], hedder det bla.: "Each stage [dvs. mikrohandling. BL] in the genre contributes a part of the overall meanings that must be made for the genre to be accomplished successfully $(\mathrm{Eg}-$ gins 1994, 36) «.

Just as cach genre has a communicative purpose that it tends to serve, similarly, each move [dvs. mikrohandling. BL] also serves a typical communicative intention which is always subservient to the overall communicative purpose of the genre (Bhatia 1993, 30)

Idet en mikrohandling er defineret ved $\sin$ funktion og ikke $\sin$ form, hedder det hos Eggins bl.a.:

We recognize as stages only those turns or groups of turns that fulfil a function relative to the whole. We therefore only call something a stage if we can assign to it a functional label « (Eggins 1994, 38).

Sproglige mikrohandlingers form anskues i funktionel angelsaksisk genretcori som mảden, hvorpå en mening er udtrykt i et (givet) semiotisk system og beskrives som de leksikogrammatiske strukturer, som er karakteristiske for det tekstsegment, der udforer en given mikrohandling (10). H vis vi eksempelvis koncentrerer os om mikrohandling 3 i Tekst 1 (ARGUMENTERE), ville en angelsaksisk inspireret beskrivelse af de formmassige aspekter af tekstsegmentet Gar som Michael Jackson, (brug Brilliant...) bl. a. omfatte folgende leksikogrammatiske fanomener: 'imperativ', 'sammenligning' og 'proprium'. Hvis det segment der udforer samme mikrohandling havde haft en anden form - f.eks. Brilliant er tilmed billigere end alle andre tilsvarende produkter - ville beskrivelsen naturligvis have varet en anden.

Mens de fleste reprasentanter for den angelsaksiske genreanalyse således udelukkende anskuer og beskriver mikrohandlingers formdimension som leksikogrammatiske strukturer, afslorede min analyse af danske sundhedsinformerende brochurer et andet vasentligt aspekt af denne dimcnsion end den leksikogrammatiske. Som illustration af dette ikke-lcksikogram-matiske aspekt af formdimensionen - som jeg valger at betegne 'taktik'-niveauetbetragt de to allerede navnte mulige udformninger af samme mikrohandling, nemlig mikrohandling 3, ARGUMENTERE:

\section{Udformning $A$ :}

Gor som Michael Jackson, (brug Brilliant...)

Udformning $B$ :

Brilliant er tilmed billigere end alle andre tilsvarende produkter 


\begin{tabular}{|c|c|c|c|c|}
\hline Makrohandling & \multicolumn{4}{|c|}{ Mikrohandinger } \\
\hline & \multirow{2}{*}{ Funktion } & \multirow{2}{*}{ Diskursiv form } & \multicolumn{2}{|c|}{ Beskrivelse af discursiv form } \\
\hline & & & $\begin{array}{l}\text { Leksiko- } \\
\text { gramm. } \\
\text { struktur }\end{array}$ & 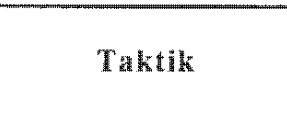 \\
\hline AT PROMOVERE & $\begin{array}{l}\text { BESKRIVE PROBLEM } \\
\text { PRASENTERE EN } \\
\text { LOSNNG }\end{array}$ & $\begin{array}{l}\text { Folder du og a d en towhed i } \\
\text { dis liv? } \\
\text { Brug Brilliant - og du wil } \\
\text { blomstre op igen }\end{array}$ & $\begin{array}{r}1 \\
-\quad \\
\vdots \\
\vdots \\
-\quad \\
\vdots\end{array}$ & 更 \\
\hline & $\begin{array}{l}\text { ARGUMENTERE } \\
\text { TLLSK YNDE TUL HANDLING }\end{array}$ & 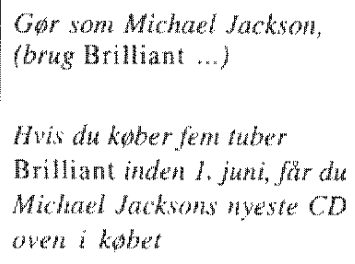 & $\begin{array}{l}\text { Imperatik, } \\
\text { sammenligning, } \\
\text { proprium ete. } \\
-\end{array}$ & - \\
\hline
\end{tabular}

Fig. 3. Nivauer i beskrivelsen af sproglige handinger eksemplificeret pả handlingen at promovere produktet Brillant; som denerudforti Tekst.

Efter min opfattelse udgør en beskrivelse af de to udformningers leksikogrammatiske aspekter ikke en tilfredsstillende redegørelse for de to udformningers forskelle. Der er mere på spil end leksis og grammatik. Foruden forskelle m.h.t. leksikogrammatiske strukturer, udviser de to udformninger nemlig også forskelle m.h.t. konceptuelt omdrcjningspunkt. Idet den udnytter den idolstatus, Michael Jackson har blandt unge mennesker, søger udformning $A$ således at overbevise modtageren om, at der ligger en social prestige $\mathrm{i}$ at anvende det samme produkt som Michacl Jackson - en social prestige som konkurrerende produkter - iflg. tekstproducenten - ikke kan tilbyde. Udformning $\mathrm{B}$, derimod, bruger Brilliants lave pris som argument for at valge Brilliant fremfor et konkurrerende produkt. Hvis de indsættes i samme kontekst, udfører de to tekstsegmenter med andre ord samme mikrohandling (nemlig ARGUMENTERE), men anvender forskellige taktikker i handlingens udforelse. Taktikbegrebet indfanger altså et aspekt af sproglige mikrohandlingers formdimension, idet det beskriver den kommunikative idé, som tekstproducenten har valgt at artikulere en given mikrohandling omkring (11). Fig. 3 opsummerer dette afsnits metodiske overvejelser.

Ovenfor har vi set, at de centrale begreber 'funktion', 'diskursiv form', 'leksikogrammatiske struktu- rer' og 'taktik' beskriver henholdsvis funktionelle og formmassige forhold ved dele af diskurser. Năr et diskurssegment (i fig. 3 angivet som 'diskursiv form') anskues i et funktionelt perspektiv, fokuseres der på den opgave, som det paggzeldende diskurssegment loser i relation til den opgave, som hele diskursen har til formål at lase. Năr et diskurssegment anskues $i$ et leksikogrammatisk eller et taktisk perspektiv, er der tale om beskrivelse af bestemte aspekter af segmentets diskursive form.

De foregăende siders metodiske overvejelser gor det nu muligt at precisere undersegelsens ambition om at beskrive kommunikationsstrategier i danske sundhedsinformerende brochurer. Idet jeg i denne artikel ser bort fra brochurernes leksikogrammatiske aspekter, er det undersøgelsens formål at undersøge, hvilke mikrohandlinger og taktikker producenteme af de analyserede 13 brochurer har valgt at anvende med henblik på at fo de intenderede modtagere til at påtage sig $\mathrm{cn}$ sundhedsmassigt mere hensigtsmassig adfard.

\section{Resultater}

Resultaterne af undersegelsen viser, at selvom de 13 brochurer langtfra har samme funktionelle makrostruktur, sả kan der konstateres et relativt stort sammenfald i denne henseende. Visse mikrohandlinger forekommer dog kun $i$ én af de 13 tekster. På 
grund af deres relative sjaldenhed er disse mikrohandlinger ikke interessante i denne sammenhang, hvorfor de lades ude af betragtning. Her vil jeg koncentrere mig om 5 mikrohandlinger, som vistc sig at vare meget hyppigt forekommende. Disse mikrohandlinger forekommer i mindst 9 af de 13 tekster og 2 af disse 5 hyppigt forekommende mikrohandlinger optrader i alle 13 tekster. De pågaldende fem mikrohandlingers funktionelle vardi fremgår af fig. 4 (tallene i parentes angiver antallet af tekster, hvori den pågaldende mikrohandling optrådte).

\begin{tabular}{|l|}
\hline KRITISERE MODTAGERS ADFARD $(10)$ \\
\hline ANBEFALE ALTER NATIVADFERD (13) \\
\hline BEGRUNDE (13) \\
\hline ATLIVE MYTER (9) \\
\hline $\begin{array}{l}\text { HENVISE MODTAGER TIL YDERLIGERE } \\
\text { INFORMATION }(10)\end{array}$ \\
\hline
\end{tabular}

Fig. 4. Prototypisk funktionel makro-struktur i 13 danske sundhedsinformerende brochurer

Det skal understreges, at ingen af de undersogte 13 tekster fandtes at have en struktur bestaende udelukkende af de næunte 5 mikrohandlinger. Fig. 4 skal derfor betragtes som en prototypisk funktionel makrostrukturel losning af den kommunikationsopgave, der består $i$ at fả en bredt defineret dansk mălgruppe til at andre adfard. Da der ikke kunne påvises nogen altdominerende indbyrdes rakkefolge mellem de fem mikrohandlinger, skal fig. 4 udelukkende ses som udtryk for, hvilke mikrohandlinger, tekstproducenteme typisk foretager og ikke for en rakkefolge, mikrohandlingerne kunne tænkes at blive foretaget i. Endvidere er det karakteristisk for flere af teksterne, at en given mikrohandling udfores ved hjolp af et antal tekstsegmenter, men at segmenterne ik ke nodvendigvis fysisk folger umiddelbart efter hinanden. Det vil sige, at mikrohandlingen BEGRUNDE i en bestemt brochure eksempelvis udfores af tre tekstsegmenter, hvoraf de forste to meget vel kan være plaw ceret på brochurens side 2 og det sidste på brochurens side 5 .

Nedenfor vil hver af de fem prototypiske mikrom handlinger og de taktikker, der er anvendt i deres udformning blive beskrevet $\mathrm{og}$ illustreret med teksteksempler. I teksteksemplerne har jeg vha. understregning markeret de elementer, det cr vasentligt at bemærke.

\section{Mikrohandlingen KRITISERE MODTAGERS ADFAED}

Afsender informerer modtager om, at afsender vurderer en bestemt adfard (hos modtager) som verende »dårlig«/»uhensigtsmassig«/»forkert«. Det afgorende $i$ denne handling er med andre ord, at afsender foretager en (negativ) vurdering af modtagers adferd.

Falles for alle udforminger af denne mikrohandling er, at afsenders kritik af modtagers adfard formidles på en indirekte maide, formentlig for at undgå at støde modtager og derved risikere, at modtager afviser brochurens overordnede budskab. Denne taktik indebærer, at i stedet for at kritisere modtagers nuvarende sundhedsadfxerd i en direkte form som f.eks. Du har dälige alkoholvaner eller Du spiser for fa gransager, sa anvender tekstproducenterne forskellige teknikker, der får kritikken til at fremstå relativt afdampet. I materialet fandtes mindst fire forskellige nedtoningsteknikker, der har det tilfalles, at den enkelte modtager af brochuren kun kritiseres indirekte:

1) Målet for kritikken udvides til at omfatte såvel afsender som modtager. Teksten kan m.a.o. 1æses således, at modtager ikke er svarreu end alle andre. Eks.: $\gg \mathrm{Vi}$ spiser for lidt gront og frugt«.

2) Der abnes mulighed for, at modtager kan slutte, at han ikke cr omfattet af kritikken. Teksten kan m.a.o. leses således, at kritikken kun vodrorer »de andrew. Eks.:

"Selvom alle ikke drikker lige meget (...) "

"De fleste unge er fornufige og ansvarsfulde. Men når det kommer til sex, sker det alligevel, at alt for mange glemmer kondomet. «

"Men $i$ nogle situationer udvikler hyggen sig til en tragedic, når sprit og trafik bliver blandet sammenk

3) Kritikken gøres upersonlig og generel og omfatter dermed ikkeblot modtager, men 'alle' (eller ingen!). Eks.:

»At spise er også et spørgsmål om vaner - og vanerkan andresa

"Det, der skal til, er en ny balance i maden. Man 
skal have vendt om pa begreberne om, hvad der er det vigtigste pả en tallerken - og hvad er der tilbehor (...). Kodet derimod kan man roligt skare ned på. Man behøver slet ikke 200 gram kod for at blive mæt

Det er interessant at bemarke, at ovenstående tekstuddrag - som er meget indirckte i sin appel til modtageren - adskiller sig fra tonen i resten af den brochure, som det stammer fra. Mens brochuren $i \sin$ helhed er praget af uformel og direkte henvendelse til modtageren (bl.a. brug af $d u$-form), ser vi altså i det segment, der har til opgave at kritisere modtageren et klart skifte i graden af direkthed i forholdet mellem afsender og modtager.

4) Kritikken fokuserer ikke på den/de person(er), der udforer den » forkerte « adfard, men pai selue adfarden.. a) Afsender beskriver adferden i et negativt lys. Eks.: Det er simpelthen gammeldags at ryge . (..) Det er umoderne at være ryger «. b) Afsender refererer én eller flere respekterede instansers (autoriteter) negative holdning til adferden. Eks.:

(..) målet med regeringens tobakspolitik er at begranse tobaksrygningens gener og helbredsskadelige virkninger for såvel aktive som passive rygere, herunder serligt at begranse tilgangen af nye rygere. WHO (..) har udarbejdet on handlingsplan for et rogfrit Europa som led i et samlet program for at opnå storre sundhed for Europas befolkning »Sundhed for alle år $2000 \ll$. Målet $e_{3}$ at i år 1995 skal mindst $80 \%$ af befolkningen i hvert land vare ikke-rygere, og tobaksforbruget skal vare nedbragt med $50 \%$.

Kommunikativ indirekthed er et relativt fanomen, som måske bedst kan beskrives som det ene yderpunkt på et kontinuum med direkthed som det andet yderpunkt. De fire beskrevne indirekthedsskabende nedtoningsteknikker ville formentlig have forskellige positioner, hvis de skulle ind. placeres $i$ et sådant kontinuum. For dem alle galder det imidlertid, at de ville placere sig tæettere på indirekthedsyderpunktet end på direkthedsyderpunktet.

Det or iovrigt iojnefaldende, at afsenderinstansen $\mathrm{i}$ langt de fleste udformninger af mikrohandlingen KRITISERE MODTAGERS ADFERD er meget udvisket. Således er udforelser som de nedenstående, hvor det relativt tydeligt markeres, at der er tale om afsenderinstansens vurdering af den tematiserede adfard, undtagelser fra reglen om, at afsenderinstansen holder sig i baggrunden:

Heldigvis er der farre der begynder at ryge

\section{(...) må give anledning til bekymring.}

Sundhedsstyrelsen fraråder, at kvinder drikker mere end 14 genstande om ugen. Mænd bor hojst drikke 21.

\section{Mikrohandlingen ANBEFALE ALTERNATIV ADFARD}

I derne handling - som sammen med mikrohandlingen BEGRUNDE formentlig kan betragtes som genrens kernchandlinger - anbefaler afsender modtager at opfore sig på en måde, som fremstilles som værende sundhedsmæssigt mere hensigtsmæssig end modtagers nuværende adfærd.

Med hensyn til udformmingen af mikrohandlingen ANBEFALE ALTERNATIV ADFARD fandtes to forskcllige taktikker: vage og pracise handlingsanvisninger.

I tekstpassager, hvor tekstproducenterne anvender vaghedstaktikken fomuleres anbefalingerne meget bredt, hvorved laseren kun far et meget overordnet indtryk af, hvilken adfæerd afsender anbefaler. Eks.

Tæenk sundt - spis sundt.

Bliv rogfri.

Det nytter at holde op.

Motion gør livet rart at leve.

Vi håber, at rygerne kan få så meget viden om deres egen rygning (...), at de tager sig sammen til at holde op.

\section{Rigtige venner stopper spritkersel.}

I tekstpassager, hvor precisionstaktikken er anvendt, finder vi adfærdsanbefalinger, der går videre end det sloganagtige niveau, vi finder i passager, hvor vaghedstaktikken er anvendt. Her specificeres, hvad det er for en adfard, afsender anbefaler, og som oftest har disse passager form af meget konkrete og 
praktiske anvisninger til modtageren $\mathrm{m}$.h.t., hvordan det kan lykkes ham at ændre adfard. Eks.

For at fă varig forbedring af $\sin$ udholdenhed, må man dyrke motion tre gange om ugen. (...) Hvis du ikke har dyrket motion i en langere periode, bor du begynde langsomt.

Bland ikke alkohol og ga udenom drinks og cocktails. De virker uskyldige - og ryger hurtigt ned men er måske blandet af 2-3 genstande spiritus og likør. (...) Pas pá peanuts, franske kartofler o.l. Saltede ting gør torstig. Så ryger der let et par ekstra genstande »inden for vesten«.

Prav at kobe ind i omvendt rekkefolge. Kob forst de gronsager du har lyst til og som passer sammen, og valg derefter et siykke kød eller fisk. (...) Frosne gronsager er en god lasning, når madlavningen skal gå hurtigt. Tænk på hvor meget tid du sparer ved ikke at skulle rense, ordne og snitte for eksempel bonner, spinat og arter. (...). Det er en god vane at slutte middagsmáltidet med frisk, snittet frugt. Snit frugterne i store stykker, kom dem op i en skálog sat den pả bordet efter aftensmaden.

Mens de vage anbefalinger nærmest beskriver de slutmål, som afsender anbefaler modtageren at arbejde henimod, fungerer de precise anbefalinger som anvisninger på konkrete handlinger, som laeseren bør udføre for at nå til slutmâlet. I nogle brochurer er kun den ene eller den anden af de to taktikker anvendt, men i de fleste brochurer ses begge anvendt. Når begge taktikker er anvendt, prasenteres de vage anbefalinger typisk forst (og ofte $\mathrm{i}$ form af afsnitsoverskrifter og slogans), hvorefter folger de pracise anbefalinger.

\section{Mikrohandlingen BEGRUNDE}

Ved denne handling, som bla. pga. dens optraden $\mathrm{i}$ alle de undersogte brochurer kan betragtes som den anden af tekstgenrens to kemehandlinger, argumenterer afsender for den foreslåede adfardsxndring.

BEGRUNDE er en meget udbredt sproglig handling, og de udformninger vi typisk finder $\mathrm{i}$ sundhedsbrochurerne har formentlig mange fællestrak med de udforminger, vi finder i mange andre tekstgenrer. Hvis man således eksempelvis onsker at begrunde over for sine børn, at de skal lave deres lektier, kan man anvende mindst to forskellige tak- tikker. Man kan valge den indfaldsvinkel, at hvis de ikke laver deres lektier, så bliver de aldrig så kloge som deres forældre. Eller man kan valge at fokusere på, at hvis de laver deres lektier, så bliver de lige så dygtige som deres forældre. Når man skal begrunde en bestemt adfærd, kan man altså valge enten at give en negativt orienteret beskrivelse af den adferd, som man ikke anbefaler eller at give en positivt orienteret beskrivelse af den adfard, som man anbefaler. I de undersegte 13 tekster fandtes eksempler på begge taktikker.

Negatio taktik/trusselstaktik: Det får (măske) negative konsekvenser for dig, ikke at folge vore anbefalinger. Eks.:

»Hver 10. mand og hver 20. kvinde i Danmark dor af kræf, der har med tobaksrygning at gorek.

»Det er videnskabeligt fastslået, at rygere har storre risiko for hjertesygdom som folge af åreforkalkning end ikke-rygere .

$\gg$ Langt de fleste overvagtige bryder sig ikke om de overflødige kilow.

"Overvagt oger risikoen for blandt andet åreforkalkning og blodpropper«:

»Har man i sin rus smadret bilen, kan regningen blive meget dyr.Kaskoforsikringen drkker nemlig ikke ved spritkorselk.

Positiv taktik/opmuntringstaktik: Det făr positive konsekvenser for dig at folge vore anbefalinger. Eks.:

»Når man dyrker motion, bliver man ikke så hurtigt træt. Man sover bedre og har mindre behov for sovn. Man kan overkomme mere«.

»Den [sunde mad] smager godt, man bliver mat, og den er ikke mere indviklet end anden madlavning. Hertil kommer, at den ofte er billig, og at sund mad er godt for helbredet

»Din krop bliver glad for dig, når du kvitter cigaretterne. De nogne facts viser, at folk, der holder op med at ryge, lever langere. (...). Din hud vil fa mere farve og blive flottere, hår og toj vil ikke lugte af rog og dine tander vil få farre 
belagninger. Din dårlige samvittighed vil formentlig også have det bedre«.

\section{Mikrohandlingen AFLIVE MYTER}

I segmenter der udforer denne handling, fremlægger afsender visse opfattelser i rclation til brochurens emne for straks efter at tilbagevise dem som værende ukorrekte/fejlagtige. Det drejer sig om opfattelser, som afsender antager er udbredte i målgruppen, og som afsender formentlig frygter kan stille sig i vejen for modtagerens godtagelse af brochurens overordnede budskab om adfardsændring. Hvis det således eksempelvis er afsenders antagelse, at modtager har den uhensigtsmassige/ fejlagtige opfattelse, at sund mad er dyr mad, valger afsender i forbindelse med en brochure om »rigtig « kost i mange tilfxlde at tilbagevise denne opfattelse. Forklaringen er naturligvis, at en sådan opfattelse nemt kommer til at fungere som modtagers undskyldning for ikke at andre sine kostvaner.

Mikrohandlingen AFLIVE MYTER ses oftc tat sammenvavet med mikrohandlingen $\mathrm{BE}_{\text {- }}$ GRUNDE. Dette er ikke overraskende, idet tilbagevisningen af en fejlagtig opfattelse ofte baserer sig på dele af den argumentation, afsender fremforer til fordel for adfærdsændringen. I én af de analyserede brochurer tilbagevises opfattelsen af, at sund mad er dyr mad således ved at anfore, at det cr billigere at spise sig mat i grontsager end i kød, hvilket i sig selv kan fungere som begrundelse for en adfærdsændring på kostområdet.

I mikrohandlingen AFLIVE MYTER fremtrader brochurernes interaktionelle aspekt meget tydeligi, idet handlingens udformning i de brochurer, hvor handlingen optræder fremstår som en dialog mellem afsender og modtager. Denne dialogtaktik ses udfort på forskellige måder, der hver reprasenterer en særlig iscenesættelse af dialogen.

\section{Eksplicit dialog mellem afsender og modtager (Spørgsmål/svar)}

De »fejlagtige opfattelser prasenteres som modtagers eksplicitte spørgsmål, som derefter tilbagevises if form af afsenders svar. I nogle brochurer har denne variant mange trak til frelles med den traditionelle og lidt stivnede rollcfordeling mellem dia- logpartnerne, som vi kender fra lregekonsultationssituationen. Spørgsmålene afspejler patientens (her modtagerens) uvidenhed og svarene lagens (her afsenders) position som eksperten, der - ofte i abstrakte vendinger og med henvisning til videnskabelige undersogelser - giver svar på alt. Eks.:

„Vil jeg tage på hvis jeg holder op med at ryge?

Ikke nødvendigvis. Men du vil tage på i vagt, hvis du fortsætter med at spise, som du plejer. En undersøgelse har vist, at ....

\section{Er det rigtigt, at milde cigaretter er ufarlige?}

$\mathrm{Nej}$, milde cigaretter indeholder ganske lidt mindre af stofferne nikotin og tjære. Kulilteindholdet og indholdet af alle de andre ca. 4000 stoffer er det samme. Nyeste undersøgelser tyder på, at ...

Er almindelig luftforurening ikke mere skadelig end tobaksrygning?

Nej, selv den forurenede byluft i industrikvarterer indeholder ikke så store mangder af skadelige stoffer som den rog, man inhalerer fra en cigaret.《

\section{Implicit dialog mellem afsender og modtager}

Spørgsmål/svar-varianten af dialogtaktikken kan beskrives som en eksplicit dialogstruktur, fordi såvel modtager som afsender er eksplicit reprasenteret $\mathrm{i}$ teksten $\mathrm{i}$ form af et sporgsmål og et svar. I andre brochurer er modtagers »fejlagtige opfattelse ikke eksplicit til stede i teksten, men fremgår implicit af udsagn, hvis primare funktion er at prasentere den »rigtige« opfattelse. Bestemte sproglige elementer afslorer, at et udsagn fungerer som et indlag (»turn a) i en dialog mellem to parter. I nedenstående eksempler afslører de understregede tekstelementer, at der er tale om modtagers »fejlagtige opfattclse, som samtidig tilbagevises. Eks.

"Det er ikke en naturlov, at xldre er i dårlig fysisk form. Motion er vigtig for celdre, som det er det for born, unge og voksnek.

»Det er aldrig for sent at komme i gang. Også 
aldre kan gennem motion få en lettere daglig" dagk.

"De fleste hjertepatienter har også stor gavn af motion

"Det er en misforståelse, at mad med mange gronsager ikke matter. Tænk bare på en god portion skipperlabskovs, frikassé eller gule ærter. Det er mad for mand, og samtidig retter, der kan indeholde mange gronsager $*$.

\section{Dialog mellem afsender og 'folkekulturen'}

I atter andre brochurer er dialogen iscenesat som en konfrontation mellem på den ene side afsender og pá den andens side opfattelser og typer af adfrerd, som er udbredt i 'store dele af befolkningen' eller blandt 'mange mennesker'. Eks.:

Cirka haludelen of danskerne mener, at de allerede spiser tilstrakkeligt med frugt og grønsager. Det gor vi desvarre ikke. Mange tror, at en lille skâl salat til aftensmaden er alt rigeligt. Men det er det langtfra. Det forslår ikke nok. Andre tror, at man skal spise helt anderledes, spise sarlig fremmedartet mad eller spise vegetarisk mad for at spise sundt. Men det er slet ikke nodvendigt.

Frosne gronsager har ikke fortjent det dälige ry, de har hos mange mennesker. Frysning er en meget skånsom konserveringsmetode, som....

Der findes masser af gode räd om, hordan man hurtigere făr alkohol ud af kroppen. Og de er allesammen forkerte! Sort kaffe, kolde styrtebade, masser af vand, motion ... mäske føler du dig mere adru, men sandheden er, at kun din krop bestemmer farten.

Mange tror, at Klamydia er et typisk storbyfænomen. Men infektionen er også udbredt uden for de store byer.

\section{Mikrohandlingen TILSKYNDE MODTAGER TIL FORDYBELSE I EMNET}

Afsender prasenterer modtager for forskellige muligheder for yderligere engagement i det emneområde, som brochuren berorer. To taktikker for handlingens udformning er reprasenteret i datamaterialet, nemlig hhv. information om praktisk orienterede aktivitetsmuligheder og litteraturhenvisninger. Nedenstående tekstuddrag illustrerer de udformninger af mikrohandlingen, der lasger vagten pa at informere om praktisk onienterede aktizitetsmuligheder: Eks.:

"Hjerteforeningens motionsklub står for regelmassige motionsaktiviteter over hele Danmark. I klubbens blad »Motionsbladet « far du mange gode tips og ideer. Ring til Hjerteforeningen og hor nærmere om medlemskab\&.

"Lxr mere om sund og lakker mad - gå på kursus. Lad det komme an på en prøve. Mcld dig til aftenskolekursus hos LOF i sund og lækker madlavning. Send kuponen i denne folder til LOF «.

"Du kan rekvirere en rygestopguide: $\gg$ Selvfolgelig holder jeg op« (se flappen på bagsiden).

Du kan også ... «

»Nyttige telcfonnumre:

Krxftlinien, tlf. 80301030 ...

Medlemsservice, tlf. $35257500 \ldots$ «

Andre brochurer benytter en taktik, der består iat bringe en litteraturliste med relation til emneområdet. Eks.:

Vil du vide mere?

I disse boger finder du yderligere oplysninger om tobaksrygning:

Misbrugets $\mathrm{ABC}(.$.

Peter Mollerup: Tobaksrog og din krop (..)

Tobaksskaderådet har udgivet en række publikationer, hvoraf folgende kan rekvireres ved henvendelse til Tobaksskaderådets sekretariat: FOLDERE:

Til rygere og til dem, der holder af en ryger. Verdens mindste "passiv-ryger - fakta om graviditet og rygning (i samarbejde med Sundhedsstyrelsen). 


\begin{tabular}{|c|c|}
\hline FUNKTION & TAKTIK (KER) \\
\hline Kritisere modtagers adfærd & $\begin{array}{l}\text { Indirekthed } \\
\text { Eks. } \\
\text { - Vi spiser for lidt gront og frugt. }\end{array}$ \\
\hline Anbefale alternativ adfard & $\begin{array}{l}\text { Vage handlingsanvisninger } \\
\text { Eks. } \\
\text { - Tænk sundt - spis sundt. } \\
\text { Præcise handlingsanvisninger } \\
\text { Eks. } \\
\text { - Prøv at købe ind i omvendt rækkefølge. Køb forst de grønsager du har } \\
\text { lyst til og som passer sammen, og vælg derefter et stykke kød eller fisk. }\end{array}$ \\
\hline Begrunde & $\begin{array}{l}\text { Trusler } \\
\text { Eks. } \\
\text { - Hver } 10 . \text { mand og hver } 20 \text {. kvinde dør af kræft, der har med tobaks- } \\
\text { rygning at gøre. } \\
\text { Opmuntring } \\
\text { Eks. } \\
\text { - Når man dyrker motion, bliver man ikke så hurtigt trot. Man sover } \\
\text { bedre og har mindre behov for søvn. Man kan overkomme mere. } \\
\end{array}$ \\
\hline Aflive myter & $\begin{array}{l}\text { Dialog } \\
\text { - eksplicit (afsender/modtager) } \\
\text { Eks. } \\
\text { - Er almindelig luftorurening ikke mere skadelig cnd tobaksrygning? } \\
\text { Nej, selv den forurenende byluft i industrikvarterer indeholder ikke så } \\
\text { store mængder af skadelige stoffer som den røg, man inhalerer fra en } \\
\text { cigaret. } \\
\text { - implicit (afsender/modtager) } \\
\text { Eks. } \\
\text { - Det er ikke en naturlov, at aldre er i dårlig fysisk form. Motion er } \\
\text { vigtig for aldre, som det er det for børn, unge og voksne. } \\
\text { - afsender/'folkekulturen' } \\
\text { Eks. } \\
\text { - Mange tror, at Klamydia er et typisk storbyfænomen. Men infektio- } \\
\text { nen er også udbredt uden for de store byer. }\end{array}$ \\
\hline $\begin{array}{l}\text { Tilskynde modtager til } \\
\text { fordybelse i emnet }\end{array}$ & $\begin{array}{l}\text { Praktisk orienterede aktivitetsmuligheder } \\
\text { Eks. } \\
\text { - Hjerteforeningens motionsklub står for regelmæssige motionsaktivi- } \\
\text { teter over hele Danmark. I klubbens blad »Motionsbladet« får du } \\
\text { mange gode tips og ideer. Ring til Hjerteforeningen og hør nærmere } \\
\text { om medlemskab. } \\
\text { Litteraturhenvisninger } \\
\text { Eks. } \\
\text { - Vil du vide mere? I disse boger finder du yderligere oplysninger om } \\
\text { tobaksrygning: ........... }\end{array}$ \\
\hline
\end{tabular}

Fig. 5. Prototypiske mikrohandlinger (funktion og taktik) i13 danske sundhedsinformerende brochurer 
(...)

PJECER:

Fakta om tobak

Fakta om passiv rygning

(...)

OVRIGE PUBLIKATIONER:

Sarnummer af Lasepadagogen om tobak og rygning.

Arsberetninger fra Tobaksskaderådet

Passiv rygning - eksposition og helbredsmassige konsekvenser. Rapport fra arbejdsgruppe nedsat af Tobasskaderådet.

(...)

I enkelte brochurer ser man begge taktikker anvendt (evt. med hovedvagten lagt på den ene), men for de fleste brochurers vedkommende galder det, at kun den ene af de to taktikker er anvendt.

Figur side 76 opsummerer undersagelsens resultater.

\section{Afsluttende bemærkninger}

Denne undersøgelses resultater tyder på, at sundhedsinformerende brochurer af den undersøgte type til en vis grad er skåret over samme lest. Fem mikrohandlinger udgor genrens prototypiske rygrad, forståct på den måde at ikke alle fem mikrohandlinger nødvendigvis findes i alle brochurer, men at de pägxldende mikrohandlinger er højfrekvente i og dermed karakteristiske for denne tekstgenre. Hvad angår taktikkerne, så har det ikke varet undersøgelsens mål, at undersoge deres hyppighed i/representativitet for genren, men udelukkende at registrere, hvilke taktikker der var anvendt $i$ det analyserede brochuremateriale.

Resultaterne har relevans for beskrivelsen af sundhedsinformerende brochurer som lekstgenre, men tillader os naturligvis ikke at konkludere noget, der har gyldighed for alle sundhedsinformerende brochurer. Enhver sundhedsbrochure er en unik kombination af de fleste af de beskrevne mikrohandlinger og taktikker og som regel nogle flere.

På baggrund af resultaterne kan man imidlertid konstruere nogle af genrens arketyper. Jeg skal her skitsere to, nemlig den $»$ traditionellek og den $»$ moderne« (12).

Den straditionellex sundhedsinformerende brochure er abstrakt, alvorlig, videnskabelig og praget af en let formanende tone. Den anbefalede alternative adford (mikrohandling 2) beskrives typisk på et meget generelt plan (vaghedstaktik), mens begrundelsen (mikrohandling 3) er negativt orienteret (trusselstaktik) med referencer til statistiske undersogelser vedrorende de negative konsckvenser af $i k k e$ at folge brochurens anbefalinger. Endvidere indgår relativt abstrakte og tekniske beskrivelser af den kritiserede adfards påvirkning af den menneskelige krop. Myter aflives (mikrohandling 4) $\mathrm{i}$ en form, der minder om lagekonsultationssituationen (taktik: eksplicit dialog mellem afsender og modtager). Denne brochuretypes form er starkt praget af afsenderinstansens ekspertstatus, og kommunikationen fremstair som en kommunikation mellem parter, der ikke er ligevardige. Budskabets form er kun i ringe grad relateret til modtagerens situation og erfaringsverden.

Den »moderne« sundhedsinformerende brochure er på mange måder den $»$ traditionelles 4 modsxtming. Den er konkret, jordnær og preget af en frisk tone. Den anbefalede adfard (mikrohandling 2) beskrives meget konkret, pracist og på en måde, der relaterer den til modtagerens dagligdag (pracisionstaktik). Mens den »traditionelle begrundelse (mikrohandling 3) er negativt orienteret, så er den »moderne « positivt orienteret, dvs. der lagges vagt på de personlige fordele, som modtageren vil kunne drage af at følge brochurens anbefalinger (opmuntringstaktik). Som det er tilfaldet for mikrohandling 2 , så tilstræbes også begrundelsen relateret til modtagerens hverdagsunivers. Brochuren er let tilgangelig, idet den ikke indeholder tekniske beskrivelser og kompliceret talmateriale. I den »moderne« brochure gor afsenderen, hvad han kan for at sløre, at der er tale om kommunikation mellem en ekspert og en lagmand. Afsender og modtager fremstår som ligeværdig og kommunikationen er proget af en kammeratlig og optimistisk tone, som man også finder i visse typer af reklamer for forbrugsvarer.

Det er klart, at da der jo netop er tale om arketyper, så passer de to karakteristikker ikke precist på nogen af de brochurer, der indgår i undersøgesens datamateriale. Der er tale om kunstige rendyrkninger af tendenser, som kan spores i datamaterialet.

\section{Noter}

1. Jeg takker mine kolleger Inger Askehave, Winni Johansen og Jan Engberg for frugtbare diskussioner af forskellige aspekter af dette arbejde.

2. Idet folgende skelnes ikke mellem brochurer og foldere. 
3. Den eksisterende danske litteratur om sundhedsinformation/moplysning synes at vate overvejende adfardspsykologisk og sociologisk orienteret (cf. litteraturliste). Blandt de centrale temaer i disse tilgange til omrădet kan navnes befolkningsgruppers sygelighed og sundhedsvaner; individers og gruppers handlingsmonstre og muligheden for at pavirke disse; effektmalinger af sundhedsinformation. De relativt fa arbejder der isar beskxfiger sig med kommunikative aspekter fokuserer bla. pa modtagere og medier, men ikke pá budskabernes udformning. Det har ikke varet muligt at finde publicerede empiriske analyser af danske sundhedbudskabers retoriske udformning.

4. Se appendix for en oversigt over de analyserede brom churer"

5. Sundhedsinformerende aktiviteter ivarksattes af savel offentlige som private instanser. Nogle af de mest aktive or Sundhedsstyrelsen, Sundhedsministeriet, amterme, Kraftens Bekrempelse, Hjerteforeningen, Astma- og allergiforbundet og Tobaksskaderådet. Se Gry Poulsen, Meillier, Mathiesen, Gamst og Kofoed 1993 for en oversigt over aktorer inden for sundhedsinformationsomridet i Danmark.

6. Det erklart, at layout og illustrationer udgor en ikke uvesentlig del af budskabets form. De rapporterede resultater vedrorer imidlertid udelukkende brochurernes sprogligt-tekstuelle aspekter.

7. Det er naturligvis muligt at udfore makrohandingen 'at vaske vinduer' ved en anden konfiguration af mikrohandlinger. Eksempelvis kan man forestille sig samme makrohandling udfort $v$ h. a. blot to af de tre nixvnte mikrohandlinger, feks. 2 og 3 eller $\log 2$.

8. Teksten er konstrueret med et illustrativt formål for ofic.

9. Hos Bhatia (og Swales) benavnes den funktionelle makrostruktur move-structure.

10. I litteraturen omtales udforelsesdimensionen ofte som lingutstic realisation pattems eller lexico-grammatical structures.

11. Se Laursen under udgivelse for en fyldigere behandling af taktikbegrebet.

12. Undersogelsens resultater tillader ikke at konkludere noget mht. genrens diakrone udvikling. Arketypebetegnelserne $\gg d e n$ traditionelle« og $\gg$ den moderne har således intet empirisk grundlag.

\section{Litteratur}

Bhatia, V. K. (1993): Analysing Genre: Language Use in Profesional Setuings. London: Longman.

Brink Lund, A. (1991): Evaluering of Sundhedsstyrelsens indsats $i$ dansk ADOS-oplysning 1987-1990. Sundhedsstyrel sen.

Brink Lund, A. og K. Marosi (1992): Vedr. Alkohol: Evahering af Studhedssyrelsens alkoholkampagne. Roskilde Universitetscenter.
Eggins, S. (1994): Ar Introduction to Systemic Functonal Linguistics. London: Pinter.

Eggins, S.og J. R. Martin (1997): Genres and Registers of Discourse. In: T. van Dijk (ed): Discourse as Structure and Process. Vol. 1. London: Sage. Pp. $230-256$.

Gry Poulsen, J., L. Meillier, J. Mathiesen, B. Camst og S. Kofoed (1993): Sumbedsoblysning i Danmark. Koben havn: Komiteen for Sundhedsoplysning i Danmark.

Laursen, B. (under udgivelse): Conceptual Tactic: An Underexplored Aspect of Communication Strategy in the Fidd of Genre Analysis?

Longacre, R.E. (1992): The Discourse Strategy of an Ap" peals Letter. In: Mann, W.C. og S.A. Thompson: Discourse Description. Diverse Linguistic Analyses of a Fund ratsing Text. Amsterdam/Philadelphia: John Benjamins.

Martin, J. R. (1992): English Tex. System and Stuture. Philadelphia/Amsterdam: John Benjamins.

Meillier, L. (1988): Patientinformation og sundhedsoplyning: Roskild. Rapport fra et projekt. Evaluering og.fremtidsper. spektiver. Kobenhavn: Komitecn for Sundhedsoplys. ning:

Meillier, L. (1994): Sundhedsoplysning og forandring. Mond, oplysning og forandring of sundhedvaner. Rapport nr. 9 . Institut for epidemiologi og socialmedicin. Arhus Universitet.

Osler, M. (1994): Livsstil og forebyggelse. Kobenhavn: TADL.

Paltridge, B. (1993): Writing up research: a systemic funcm tional perspective. In: System, vol. 21, no. 2, pp 175-192.

Swales, J. M. (1990): Genre Analysis - English in Academic and Research Settings. Cambridge: Cambridge U.P.

Thune Jacobsen, E. (1994): Sundhed soplysende kampagner. Et litteraturstudie af afsenderperspektivet. Dansk Sygehus Institut.

\section{Appendix}

Undersøgelsens datamateriale

Kort om motion og dit hjerte. (Hjerteforeningen 1991)

Kort orn sund og lakker mad. (Hjerteforeningen 1990)

Kort om overvagt og dit hjerte. (Hjerteforeningen 1990)

Vard at vide on rygning. (Kraftens Bekampelse 1985)

Bliv stark bliv rogfri. (Kreftens Bekrmpelse 1995)

Trenk sundt spis sundt. (Kraftens Bekempelse 1995)

Kort om tobak og dit hjerte. (Hjerteforeningen/Tobaksm skaderädet 1990)

Rygeophor - uden at tage på. (Tobaksskaderådet 1989)

Fakta om tobak. (Tobaksskaderadet 1989)

Obs pa tobak. (Kraftens Bekxmpelse, udgivelsesăr ukendt)

Spring genstandene over til hverdag. (Sundhedsstyrelsen 1993)

Kxorlighed uden Klamydia. (Sundhedsstyrelsen 1990)

En farlig cocktail (Radet for Storre Fardselssikkerhed 1989)

Bo Laursen er lektor ved Fransk Institut, Handelshojskolen i Ârhus 


\section{Anmeldelser:}

Medieudvalgets rapportserie, 1995-96

anmeldes af Carsten Ohlmann

Mustafa Hussain, Ferruh Yilmaz og Tim O'Connor: Medierne, minoriteterne og majoriteten - en undersogelse af nyhedsmedier og den folkelige diskurs $i$ Danmark. Nævnet for Etnisk Ligestilling, 1997

anmeldes af Hanne Løngreen

Angharad N.Valdivia (ed.): Feminism, Multiculturalism, and the Media: Global Diversities, Thousand Oakes, California: Sage Publications, 1995

anmeldes af Hanne Chone

Kirsten Drotner et al.: Øjenåbnere. Dansklærerforeningen, 1996

Kirsten Drotner et al.: Tankestreger. Borgen/Medier, 1997

Torben Fridberg et al.: Mønstre i mangfoldigheden. Borgen/Medier, 1997

anmeldes af Tem Frank Andersen 